Original Article

\title{
POLLEN FORAGING BY HONEY BEES (APIS MELLIFERA L.) IN GREECE: BOTANICAL AND GEOGRAPHICAL ORIGIN
}

\author{
Maria Dimou* \\ Chrysoula Tananaki \\ Vasilios Liolios \\ Andreas Thrasyvoulou
}

Laboratory of Apiculture and Sericulture, Faculty of Agriculture, Aristotle University of Thessaloniki, Greece

*corresponding author: mdimou@agro.auth.gr

Received 25 September 2013; accepted 25 July 2014

\begin{abstract}
A b s tract
Pollen is very important for honey bee colony development and nutrition. It is also a valuable product for human consumption, considered to have high nutritional value. In this study, we performed melissopalynological analysis of 285 pollen load samples collected from 44 apiaries throughout Greece. The analysis revealed 229 plant taxa represented in total. The abundance of each pollen type varied among the geographical areas from which the samples were collected. We also observed variation among samples collected from the same geographical region. The most frequently found families were Fabaceae, Asteraceae and Rosaceae. The most frequently observed taxa were Brassicaceae, Carduus type, Cistus and Papaver rhoeas. Statistical analysis showed that the geographical classification of pollen samples among northern, central and southern Greece is possible.
\end{abstract}

Keywords: Apis mellifera, botanical origin, geographical origin, Greece, melissopalynology, pollen.

\section{INTRODUCTION}

Honey bees depend on nectar and pollen to sustain themselves. Pollen provides lipids, carbohydrates, vitamins, and minerals to the colonies; and it serves as the honey bees' only protein source (Roulston and Cane, 2000). Pollen is necessary for brood and young worker development, thus, colony survival and growth depend on the quantity and the nutritional quality of the pollen resources provided by the foragers. The shortage of pollen can have significant effects, both on the strength and resilience of the colony and on honey production (McLellan, 1974). Nutritional quality, as well as quantity, is important. Pollen containing less than $20 \%$ crude protein cannot satisfy the colony requirements for its development and optimum honey production (Herbert, 1992). Pollen collected from different plant species has different nutrient value and may differ significantly in amino acid composition and/or concentration (Day et al., 1990; Roulston et al., 2000). Thus, knowledge of the composition and diversity of the pollen sources within an area is very important to the local beekeeping industry.

Pollen is also considered to be a product of high nutritional value for human consumption. During recent years, its demand has been continually increasing in the world market (Villanueva et al., 2002). Because the composition of commercial pollen varies greatly depending on the botanical and geographical origin (Linskens and Jorde, 1997), the proper labeling of the product for human use necessitates an understanding of these parameters.

Greece is located in the center of the eastern Mediterranean, at the junction of Africa, Asia, and Europe, creating a habitat with a rich and diversified flora (Phitos et al., 1995). The rich flora and territorial diversity, along with the abundant sunshine, create a unique environment for the development of apiculture. Beekeeping plays a very important economic role; about 20,000 families in Greece maintain over 1.5 million honey bee colonies (Papa- 
panagiotou, 2010). Although several studies have addressed nectar sources and honey types produced in Greece (Thrasyvoulou and Manikis, 1995; Tsigouri et al., 2004; Dimou et al., 2006b; Karabournioti et al., 2006; Karabournioti et al., 2009), there are few studies about the pollen flora in Greece to date (Dimou and Thrasyvoulou, 2007a,b).

The aims of this study are: to identify the floral composition of bee pollen in main apicultural areas in Greece and to collect and provide botanical and geographical information relevant to the potential marketing of bee pollen as a commercial product.

\section{MATERIAL AND METHODS}

Pollen samples were collected from pollen traps fitted in the entrance of honey bee (Apis mellifera L.) hives during 2009 - 2012. The traps remained closed for at least three days per week and the pollen was collected weekly, as suggested by Dimou et al. (2006a). Pollen was obtained during spring and early summer (April to June), which is the main pollen season in Greece (Dimou et al., 2006a; Dimou and Thrasyvoulou, 2007a). The pollen load samples were collected from 44 apiaries corresponding to 16 prefectures of main apicultural interest in Greece. The sites varied in surrounding flora, elevation, temperature, and rainfall. The great majority of the apiaries were located in areas near both natural habitat and agricultural landscape with crops such as wheat, maize, cotton, and olive trees. All of the beekeepers who participated in this work were members of the "Hellenic Association of Royal Jelly and Other Bee Products Producers." In total, 285 pollen samples were processed: 111 samples were collected from northern Greece (Thessaloniki, Pieria, Chaklidiki, and Kilkis), 96 from central Greece (Arta, Viotia, Larisa, Phthiotis, Magnesia, Attiki, Achaea, Kefallinia, and the Cyclades islands of Tinos and Paros), and 78 from southern Greece (Chania, Lasithi, and Heraklio) (Fig. 1).

At least 300 pollen loads from each sample were sorted by color, and at least two slides of each color class were prepared without acetolysis, using similar methodology as described by Louveaux et al. (1978). Each examined pollen load was placed on a slide with a drop of a glucose solution and stained with alcoholic fuchsine. The slide was then dried by slight warming (not above $40^{\circ} \mathrm{C}$ ) and mounted with Entelan ${ }^{\text {TM }}$ (Entelan Microscopy, Karlsruhe, Germany). At least 500 pollen grains on each slide were counted under the microscope. If at least $95 \%$ of the counted pollen grains on a slide were identified to be the same type, it was considered that this pollen load was from a single floral source.

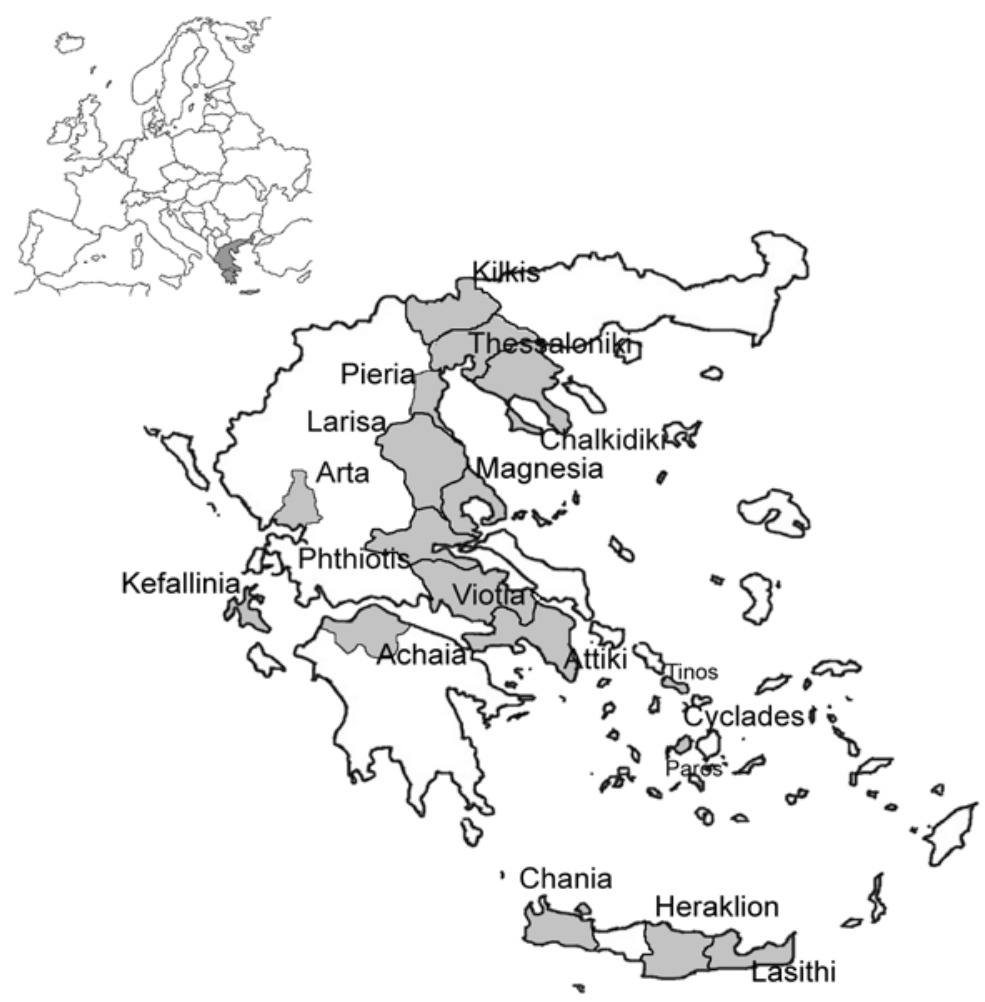

Fig. 1. Prefectures of Greece from which the pollen samples were collected. 
To determine the botanical classification of the taxa from which the pollen was derived, both color and grain morphology of the pollen load were considered (Hodges, 1974; Dimou and Thrasyvoulou, 2007b). Pollen loads with the same pollen type and color were segregated and weighed to quantitate the contribution of each individual pollen source. The following classes were defined to describe the frequency with which a botanical source is represented within a given pollen load: "class I", rare, found in $<3 \%$; "class II", very few, found in 3 - 15\%; "class III", few, found in 16 - 45\%; and "class IV", frequent, found in $>45 \%$. When a pollen load was derived from more than one botanical source, the grouping within the above classes was assigned to be proportional to the counted percentage of the pollen grains on the slides. However, such cases were very rare, and they concerned only taxa found in $<3 \%$ in the sample. For the microscopic identification of the pollen types, the collection of reference slides from the Laboratory of Apiculture of the Aristotle University of Thessaloniki and pollen atlases were used (D'Albore, 1998; Moshidis et al., 2013).

The Diversity Index of Shannon and Weaver (1949) was used to indicate the pollen type diversity and species richness:
$H^{\prime}=-\sum_{i}^{n} p_{i} \cdot \ln p_{i^{\prime}}$

where $\mathrm{H}^{\prime}$ is the Shannon-Weaver Diversity Index, and $p_{i}$ is the proportion of each pollen type i encountered in the sample.

The differences observed among the number of pollen types and the Shannon-Weaver Diversity Index pertaining to samples from southern, central, and northern Greece were statistically evaluated by ANOVA. Canonical discriminant analysis (CDA) was performed on the frequency of each taxon in the samples (independent variables), in order to classify the pollen from the three different areas of 1 : southern Greece, 2: central Greece, and 3: northern Greece (grouping variable). The analyses were carried out using SPSS 17.0 software for Windows (SPSS, Chicago, IL, USA).

\section{RESULTS}

The melissopalynological analysis of the samples revealed 64 families and 229 pollen types represented in total. The most frequently found families were Fabaceae, Asteraceae, and Rosaceae. Brassicaceae,

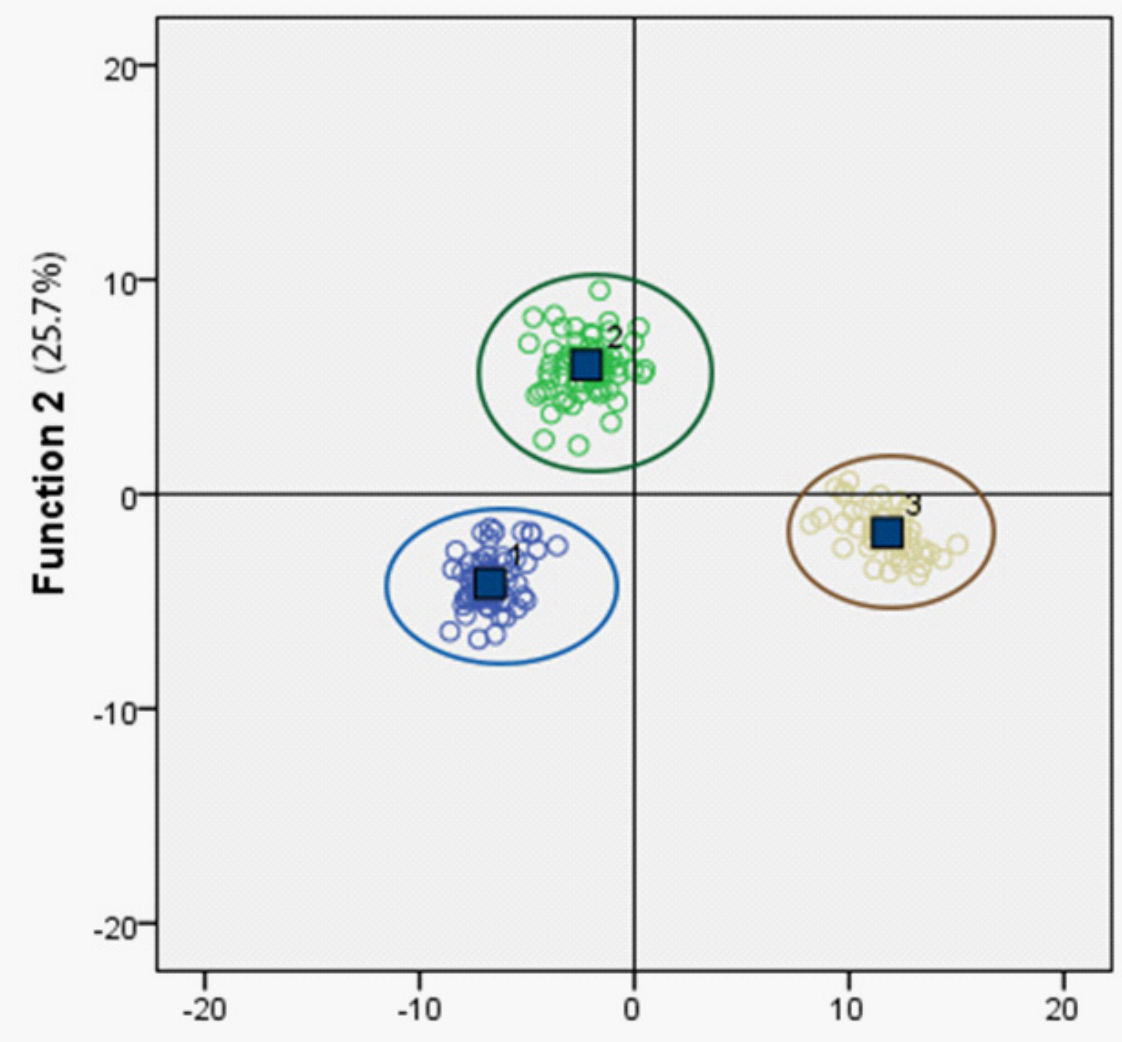

Function 1 (74.3\%)

Fig. 2. Canonical Discriminant Functions among the three geographical areas in Greece (1:

Southern Greece; 2: Central Greece; 3: Northern Greece). 
Carduus type, Cistus, and Papaver rhoeas were a single botanical source (class IV).

found in more than half of the samples (Tab. 1). The The number of pollen types found in each sample abundance of each pollen type varied among the geographical areas and among the individual samples within a given area. The majority of the samples contained pollen from several floral sources, and about $1 / 3$ of the samples were mainly derived from varied from 4 to 22, and the average and standard deviation of all samples were $12.5 \pm 4.0$ types. The Shannon-Weaver Diversity Index values ranged from 0.2 to 3.2 in the samples from southern Greece, from 0.3 to 2.4 in the samples from central Greece,

$\frac{\check{\theta}}{\frac{0}{\sigma}}$

ปें

ம่

尚

.드

믐

उे

过

品

气ิํㅡㄴ

으드

ํํำ

'่

드

믇드

는 뜬

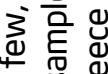

吕 d

这艺

=远

气ิ

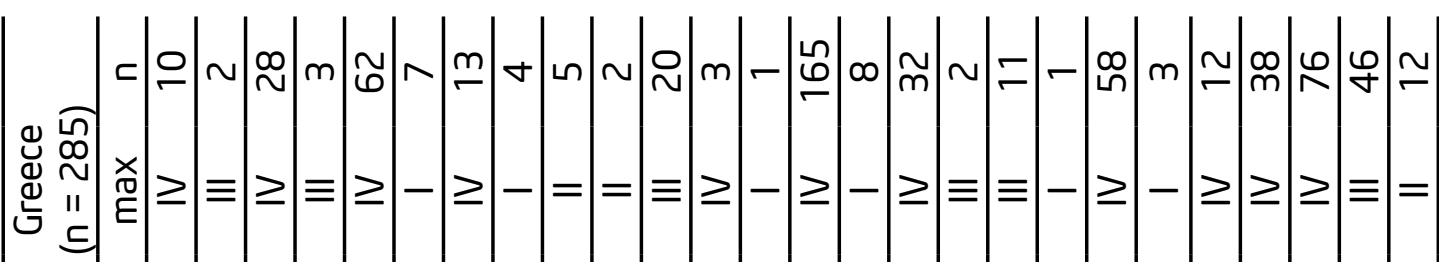

듵

ভِ

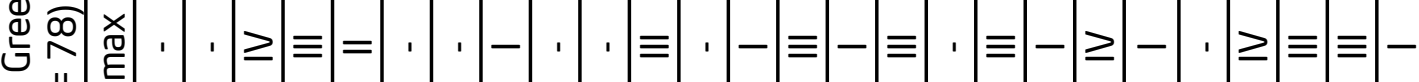
喜

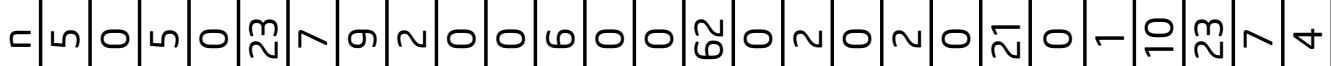

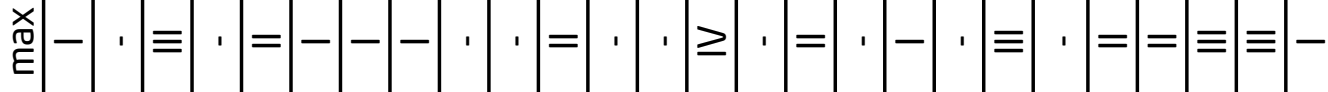
든

$\cdot \frac{\subseteq}{\mathrm{E}}$

过

E.

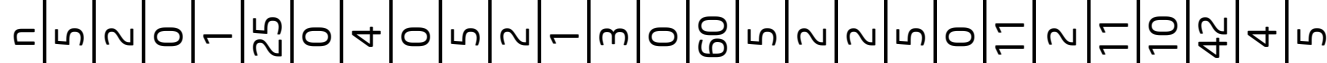

$\because \frac{0}{0}$

m

드 눗 는

므도 엉

은 믇

띤 은

든

ज웜

贻 먼

¿

气ิ气

귿

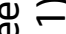

는

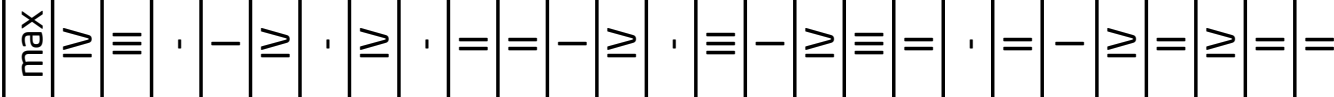
은 $ᄃ$

$\cdot \frac{.}{\mathrm{E}}-(-)-(\cdot)=$

(1)

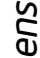

ه

$\stackrel{2}{\geq}$

$\frac{\bar{\alpha}}{\overline{0}}$

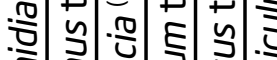

인.

$\infty \approx$

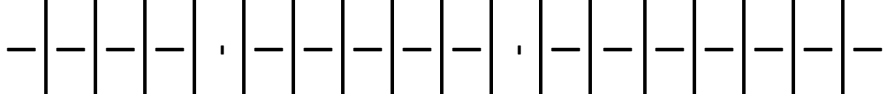

먼

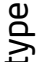

등

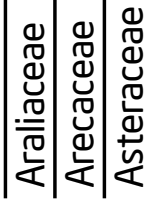




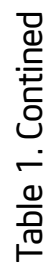

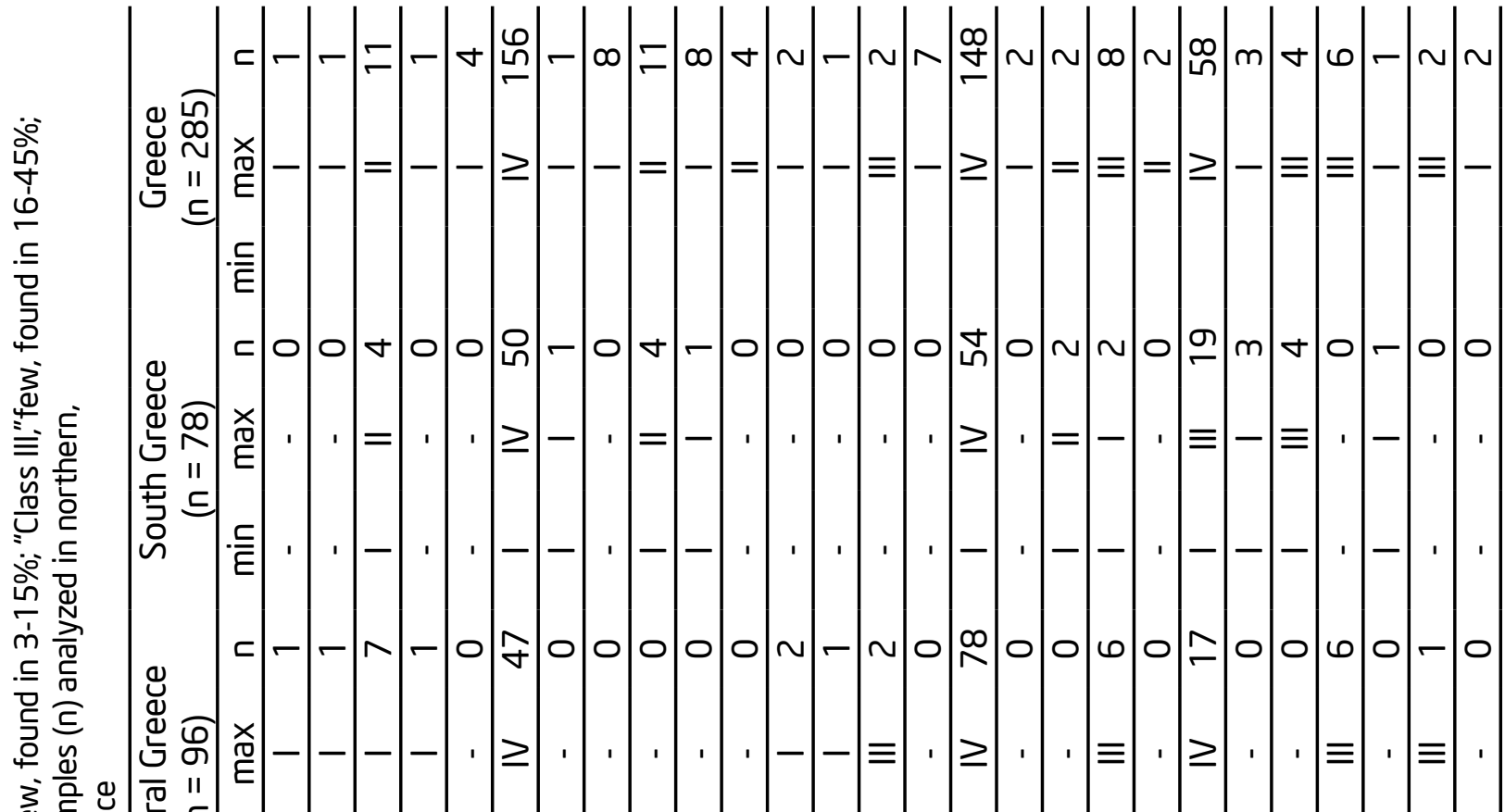

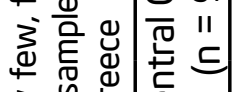

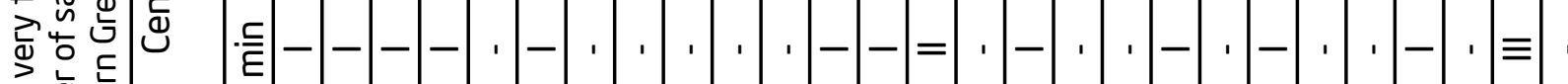
要密

岇它苛

는

这宽造

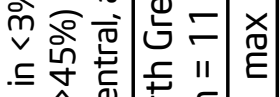

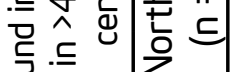

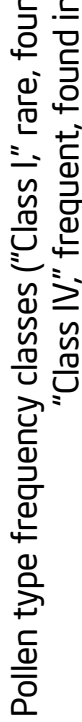
$\cdot \frac{\mathrm{E}}{\mathrm{E}}$

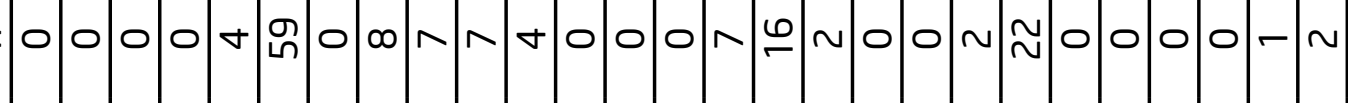

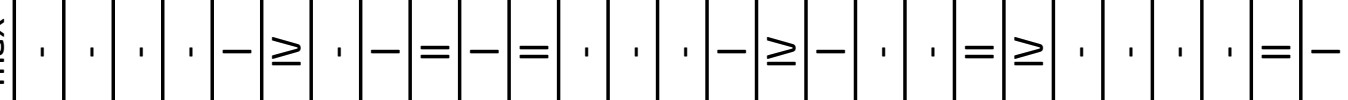
E 


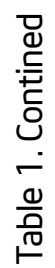

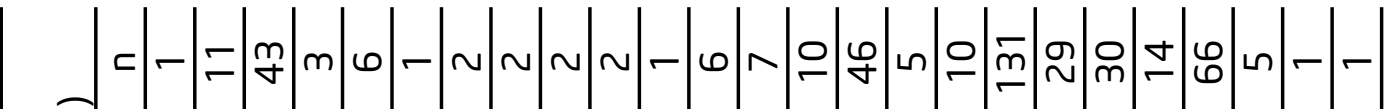
๑

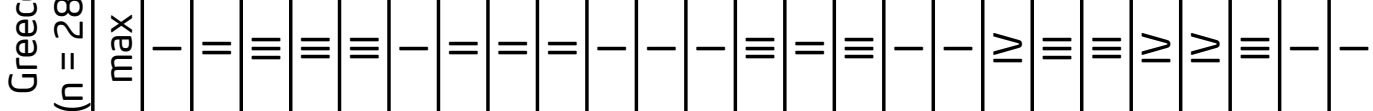

b

$\cdot \frac{\mathrm{C}}{\mathrm{E}}$

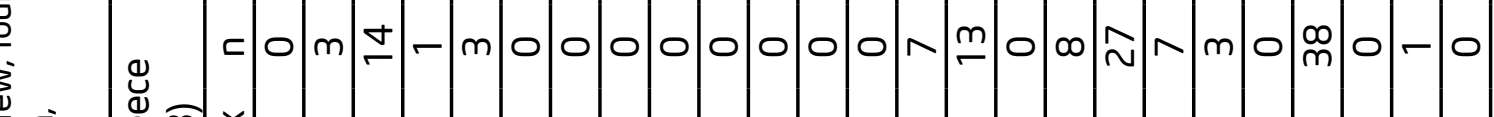

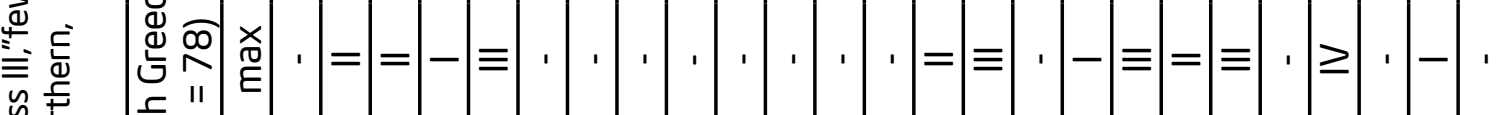
岇至

$\therefore$ 证

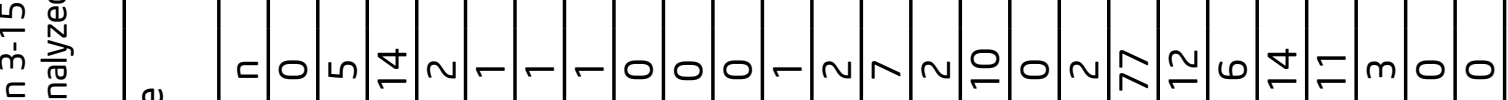
들

要

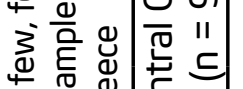

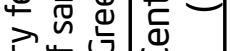

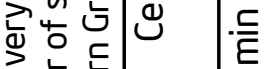

三竞

崖宅 总

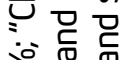

¿ㄷํㅇ

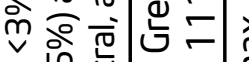

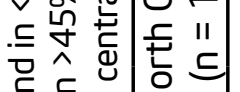

政

ㄸํㄴ

至

峞

눈

品

苋氙

Ч

강

z

들 $---1=$

空

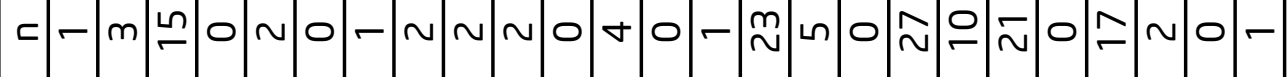

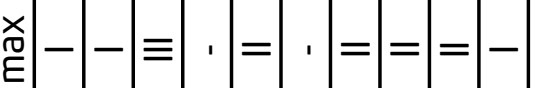

$--(\equiv-$

$=\equiv \equiv$ 


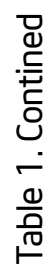

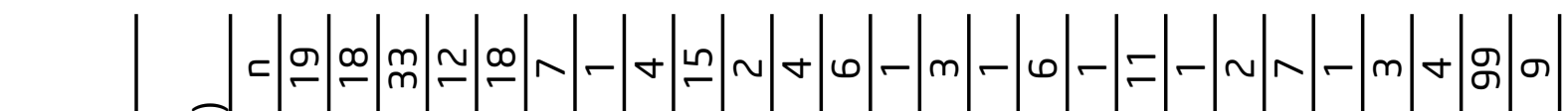

ทั

บِ

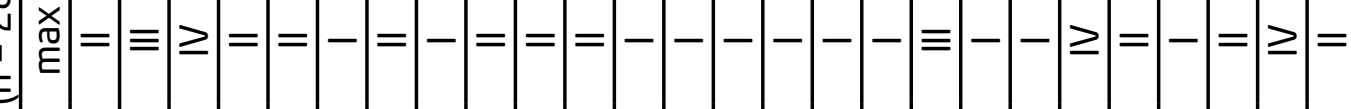
$\cdot$ 들

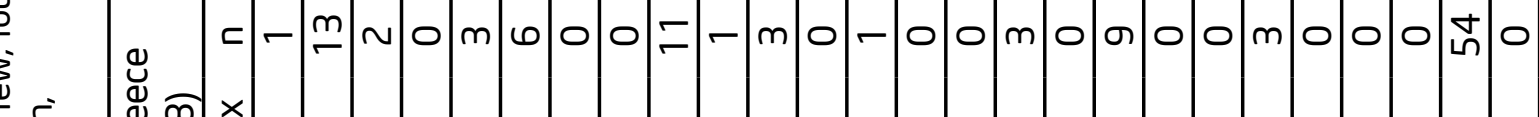

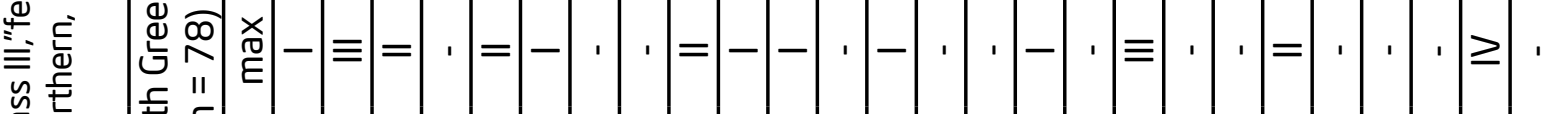
峁 늗

$\therefore$.

ํำ

m $\frac{N}{\pi}$

드 듕

气

는

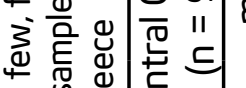

는 范

三㐫

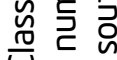

는 믄

○苗茴二

진든

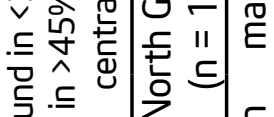

.ᄃ ---

बํํ

ज

气ิ

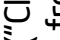

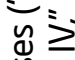

苋

Ч

خ্ড

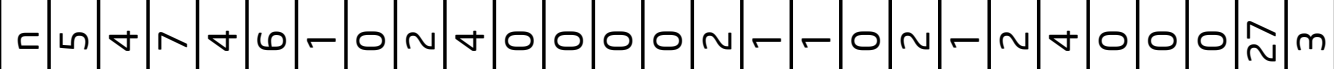

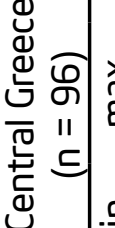

$=-\infty=-$

드 $-----(-)$

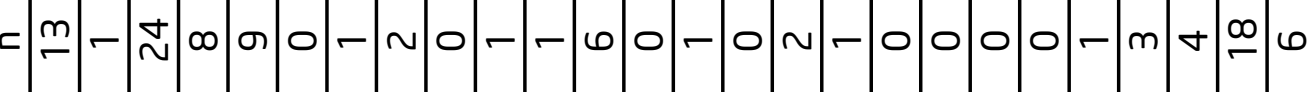

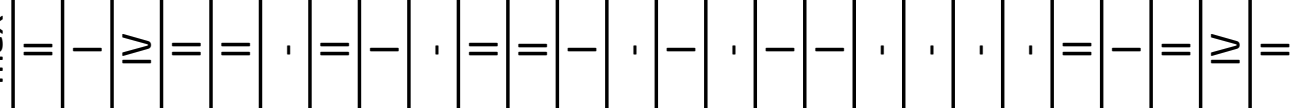

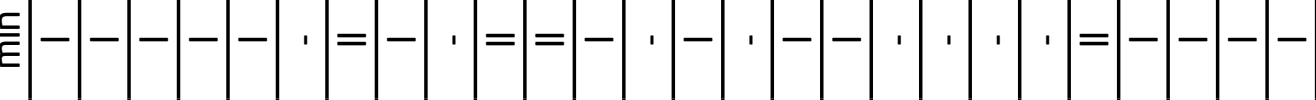
(1)

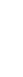

贫

约

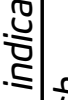

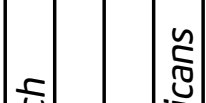

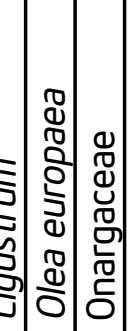

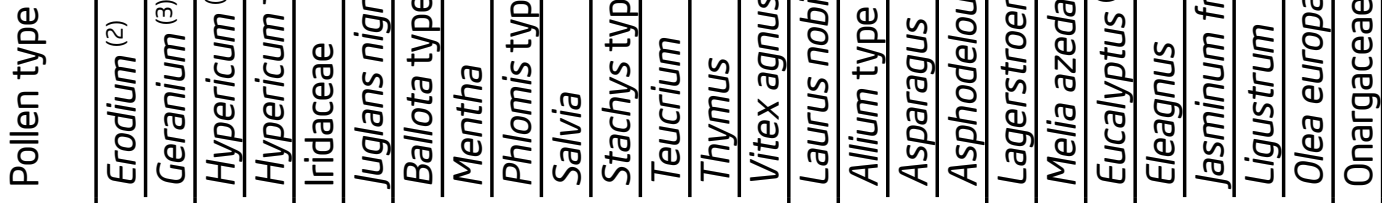

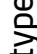

등

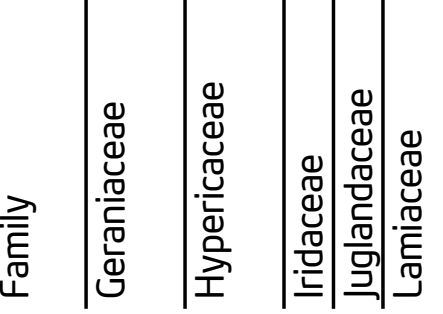

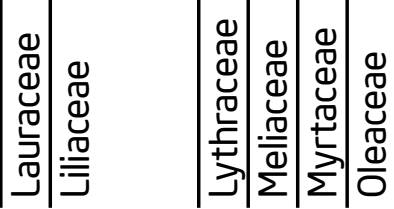

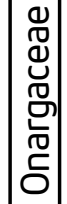




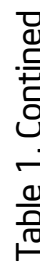

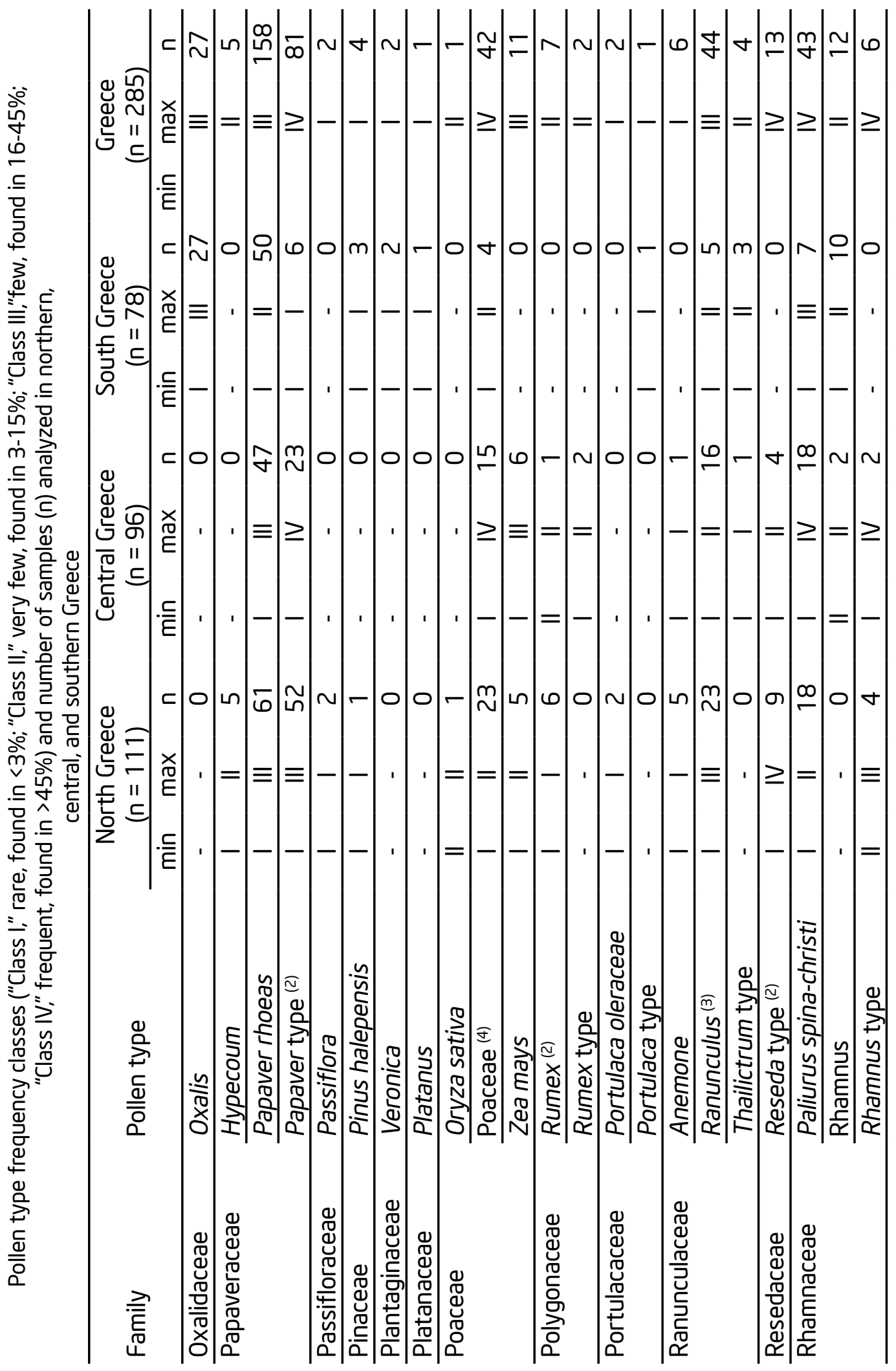




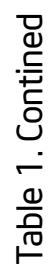

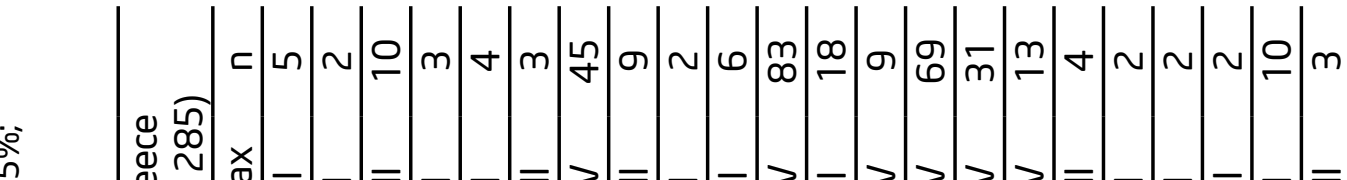

นั

$\underline{\sigma}$

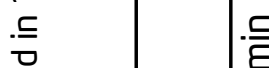

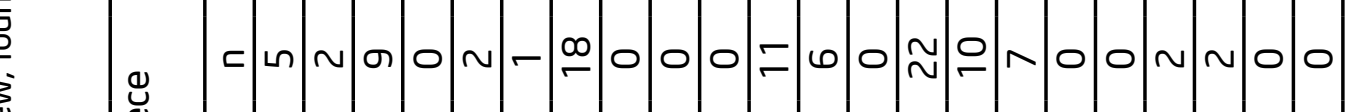

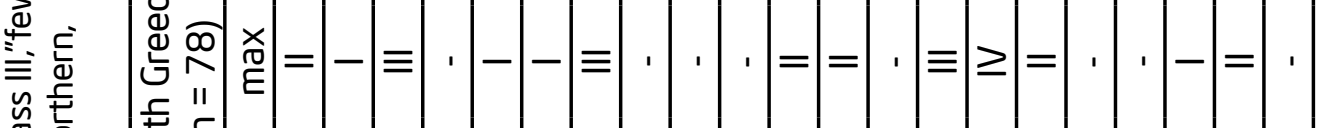
岂它

○.

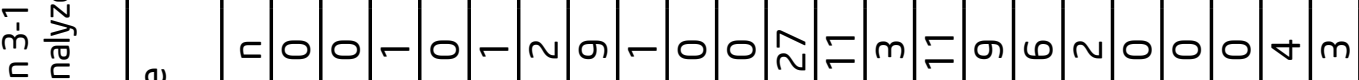
들

\section{4}

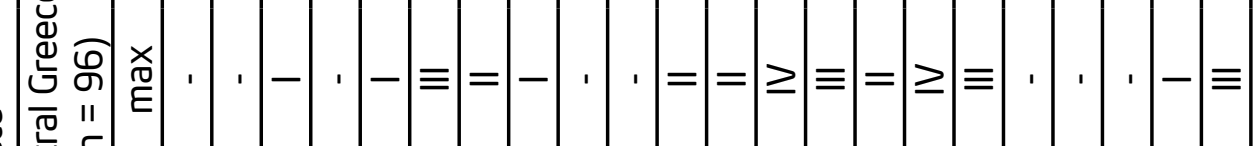

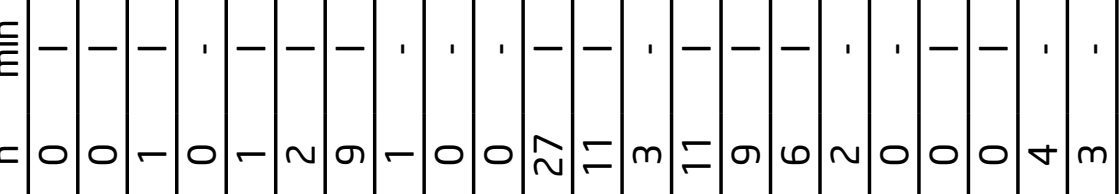

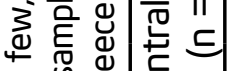

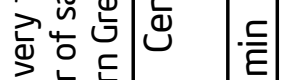

至造至

峁 究

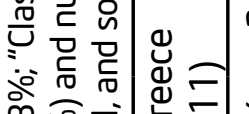

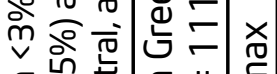

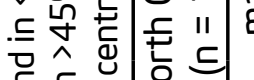

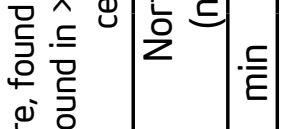

$\cdot-1 \cdot-=-$

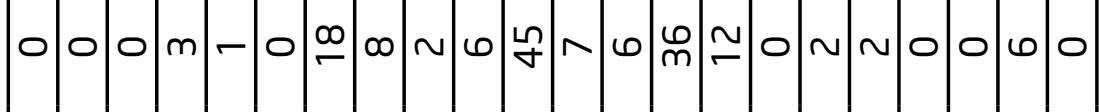
$\cdot \cdot \cdot--\mid \geq \geq=\geq=\geq=\geq$

.

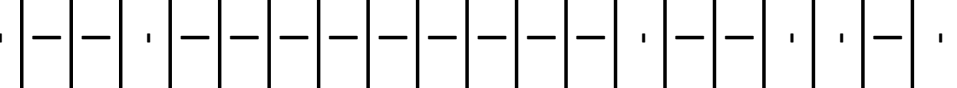

政

气̀

苍导

¿

苋茶

U

己े

8

号

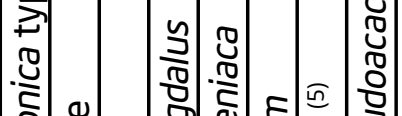

:

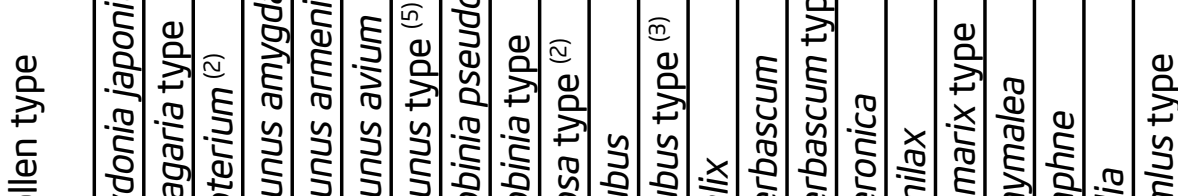

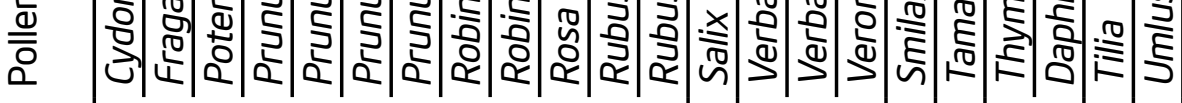

$\stackrel{2}{2}$

$\stackrel{\overline{0}}{\overline{0}}$

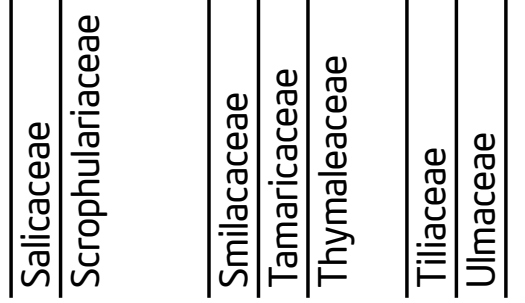


and from 0.3 to 2.1 in the samples from northern Greece. On average, the Shannon-Weaver Diversity Index value of all samples was $2.1 \pm 0.3$. ANOVA analysis showed a statistically significant difference among the three geographical areas considering the number of pollen types $(p<0.001)$ and the Shannon-Weaver Diversity Index values $(p<0.001)$. In particular, samples from southern Greece showed statistically significantly more pollen types and higher Shannon-Weaver Diversity Index values than those from northern and central Greece.

In total, 141 pollen types were identified in the samples collected in northern Greece. Brassicaceae, Carduus type, Sonchus type, Rubus, Papaver rhoeas, and Papaver type were found in a great number of samples from this area (Tab. 1). Pollen loads from Actinidia chinensis, Artemisia, Brassicaceae, Cistus, Convolvulus, Centaurea scabiosa, Daucus type, Helianthus annus, Hypericum, Olea europaea, Parthenocissus, Pastinaca, Prunus type, Reseda type, Rubus, Sonchus type, Verbascum, and Verbascum type were observed as class IV components (greater than 45\%) in samples from this locale (Tab. 1). These samples exhibited wide pollen diversity; only Brassicaceae pollen was represented in several samples (14).

Brassicaceae, Carduus type, Cistus, Papaver rhoeas, and Trifolium were found in several samples from central Greece (Tab. 1). In total, 132 taxa were identified. In 64 out of 96 samples from this area, the botanical origin of the pollen loads was mainly from a single source (class IV); and the majority of these comprised pollen from Brassicaceae and Cistus.

In southern Greece, 108 pollen types were identified. Brassicaceae, Cistus, Olea europaea, and Papaver rhoeas were detected in over $60 \%$ of the samples. Asteraceae (Carduus type, Cirsium type, Centaurea scabiosa, and Taraxacum officinale) were also identified in several cases (Tab. 1). In about 35\% of the samples from southern Greece the collected pollen was defined as class IV, mainly from Cistus plants.

Statistical analysis (CDA) showed complete separation among the three geographical areas sampled (Fig. 2). According to the classifications results, $100 \%$ of the original grouped cases and $75 \%$ of the cross-validated grouped cases were classified correctly. The statistical analysis revealed two functions. The first discriminates the pollen from northern Greece from the other two sources, especially from southern Greece; and the second discriminates the pollen from central Greece from the samples from other geographical origins, particularly from the pollen from southern Greece. 


\section{J. APIC. SCL. VQL. 58 NOV. 2 2014}

\section{DISCUSSION}

Pollen provides the sole protein source for the honey bee colonies, and it is necessary for brood and young worker bee development. Therefore, colony survival and growth depends on both the quantity and the nutritional quality of the pollen provided by the foragers in the colony. The composition of pollen harvested by honey bees can vary greatly depending on the time of year, the botanical origin, and the geographic region from which the pollen is obtained (Linskens and Jorde, 1997).

The determination of the botanical and geographical origin is fundamental in understanding pollen quality. Both parameters influence its nutrient value. They affect not only the development and survival of the honey bee colony, but also the value of the pollen as a commercialized product marketed for human consumption. Consequently, the local flora directly and indirectly affects beekeepers' profits by affecting the productivity of the honey bee colony as well as the price of the product in the marketplace.

Many authors have studied the botanical origin of pollen collected from honey bees in diverse geographical areas. Freitas et al. (2013) collected samples of pollen loads from honey bee colonies within 19 municipalities in Brazil and analyzed their sediment. They found 4 to 25 pollen types per macro region. The study conducted by Novais et al. (2010) on trapped pollen from Apis mellifera colonies in the Caatinga region of Brazil revealed 85 pollen types in samples collected within a two year period. Andrada and Telleria (2005) analyzed honey bee pollen loads in the Calden district of Argentina and recorded 29 pollen sources over two apicultural periods. Forcone et al. $(2011 ; 2013)$ collected bee pollen from the Andean region of Chubut and the region northwest of Santa Cruz (Argentinean Patagonia) and found 46 and 42 pollen types, respectively, during one apicultural season, with over 16 taxa represented per sample in some cases. Kajobe (2007) studied pollen foraging by Apis mellifera in Bwindi Impenetrable National Park (Uganda) for one year and found 71 pollen sources in total, and a Shannon-Weaver Diversity Index value of 1.5 . Wróblewska et al. (2010), in an 8-year-study of beebread in four Lublin regions in Poland, found 40, 57, 58 and 73 pollen types, respectively, in the samples collected. Dimou and Thrasyvoulou (2007a) found over 140 pollen taxa in Thessaloniki, Greece, in a two year study. Bilisik et al. (2008) recorded 41 pollen types in the Bursa region of Turkey across one apicultural period and found on average about 8 taxa per sample. During the same period, Avni et al. (2009) reported that the number of honey bee pollen sources in four distinct sites in Israel ranged from 5 to 20 taxa per sample.

However, because of the different methodologies followed in these studies (i.e., variation in time and duration of sampling, method of pollen analysis, presentation of data) it is hard to compare them to one another. In this study, the average number of pollen types detected per sample as well as the high Shannon-Weaver Diversity Index value indicates a great variety of pollen sources in the collected samples. This result is consistent with the species richness characteristic of the vegetation in Greece (Phitos et al., 1995). Pollen from different plant species has different nutrient content. Therefore, having variety and diversity of pollen types is desirable since it results in higher nutritional value within the final product. In this study, most collected samples showed the presence of Brassicaceae, Carduus type, and Papaver rhoeas pollen, which has been previously shown to have high protein content (>20\%), a characteristic that not only satisfies colony requirements for development and optimum production (Herbert, 1992; Szczęsna, 2006; Liolios et al., 2010) but can also result in a rise in the crude total protein content of the commercial product.

Finally, despite the extended bibliography on pollen foraging behavior, there is no data about possible discrimination among different geographical areas by honey bees. The results of this study enable such research by showing that the determination of the geographical origin of the honey bee-collected pollen is possible, even over areas that are relatively close to each other. Samples from northern, central, and southern Greece were clearly distinguished from each other. This observation may also support establishment of a Protected Geographical Indication or Protected Designation of Origin of the commercial product.

\section{CONCLUSIONS}

Understanding the composition and diversity of the local pollen flora is very important to the beekeeping industry of the region, both in terms of colony health and in the value of bee pollen as a commercial product. In recent years, labeling of the botanical and geographical origin of products is an increasing requirement for all foods marketed for human consumption, which is directly connected to quality control and to the consumer's perception of the product and thus its commercial value. 
In this study we show that (i) Greek pollen is characterized by a great variety of pollen sources; and (ii) determination of the geographical origin of bee pollen is possible even across small-scale areas.

\section{ACKNOWLEDGEMENTS}

This study was partially funded by the Hellenic Ministry of Rural Development and Food and supported by the "Hellenic Association of Royal Jelly and Other Bee Products Producers."

\section{REFERENCES}

Andrada A. C., Telleria M. C. (2005) Pollen collected by honey bees (Apis mellifera L.) from south of Calden district (Argentina): botanical origin and protein content. Grana 44(2): 115-122. DOI: 10.1080/00173130510010459

Avni D., Dag A., Shafira S. (2009) Pollen sources for honeybees in Israel: Source, periods of shortage, and influence on population growth. Israel Journal of Plant Sciences 57(3): 263-275. DOI: 10.1560/IJPS.57.3.263

Bilisik A., Cakmak I., Bicakci A., Malyer H. (2008) Seasonal variation of collected pollen loads of honeybees (Apis mellifera L. anatoliaca). Grana 47(1): 70-77. DOl: 10.1080/00173130801923976

D'Albore R. G. (1998) Mediterranean melissopalynology. Università degli studi di Perugia, Facoltà di Agraria. Perugia. 466 pp.

Day S., Beye R., Merce A., Ogde S. (1990) The nutrient composition of honey bee-collected pollen in Otago, New Zealand. Journal of Apicultural Research 29(3): 138-146.

Dimou M., Thrasyvoulou A. (2007a) Seasonal variation in vegetation and pollen collected by honeybees in Thessaloniki, Greece. Grana 46(4): 292-299. DOl: $10.1080 / 00173130701760718$

Dimou M., Thrasyvoulou A. (2007b) A comparison of three methods for assessing the relative abundance of pollen resources collected by honey bee colonies. Journal of Apicultural Research 46(3): 143-147. D0l: 10.3896/ IBRA. 1.46.3.04

Dimou M., Thrasyvoulou A., Tsirakoglou V. (2006a) Efficient use of pollen traps to determine the pollen flora used by honey bees. Journal of Apicultural Research 45(1): 42-46. DOl: 10.3896/IBRA. 1.45.1.10
Dimou M., Katsaros J., Tzavella Klonari K., Thrasyvoulou A. (2006b) A study on the botanical and geographical discrimination of pine and fir honeydew honeys by their microscopical characteristics. Journal of Apicultural Research 45(2): 16-21. DOI: 10.3896/IBRA. 1.45.2.04

Forcone A., Calderón A., Kutschker A. (2013) Apicultural pollen from the Andean region of Chubut (Argentinean Patagonia). Grana 52(1): 49-58. DOl: 10.1080/00173134.2012.717964

Forcone A., Aloisi P. V., Ruppel S., Muñoz M. (201 1) Botanical composition and protein content of pollen collected by Apis mellifera $L$. in the north-west of Santa Cruz (Argentinean Patagonia). Grana 50(1): 30-39. DOl: 10.1080/00173134.2011.552191

Freitas A. S., Arruda V. A. S., Almeida-Muradian L. B., Barth O. M. (2013) The botanical profiles of dried bee pollen loads collected by Apis mellifera (Linnaeus) in Brazil. Sociobiology 60(1): 56-64. DOl: 10.13102/sociobiology. v60i1.56-64

Herbert E. W. J. (1992) Honey bee nutrition. In: Graham J. M. (Ed.) The Hive and the Honey Bee. Dadant \& Sons. Hamilton, IL: 197-233.

Hodges D. (1974) The pollen loads of honeybee. Godards \& Cawley Ltd. London. 120 pp.

Kajobe R. (2007) Pollen foraging by Apis mellifera and stingless bees Meliponula bocandei and Meliponula nebulata in Bwindi Impenetrable National Park, Uganda. African Journal of Ecology 45(3): 265-274. DOl: 10.1111/j.1365-2028.2006.00701.x

Karabournioti S. E., Thrasyvoulou A., Eleftheriou E. P. (2006) A model for predicting geographic origin of honey from the same floral source. Journal of Apicultural Research 45(1): 1 17-124. DOI: 10.3896/IBRA.1.45.3.04

Karabournioti S. E., Tsiripidis I., Thrasyvoulou A., Eleftheriou E. P. (2009) Melissopalynological attributes of some Greek thyme honeys. Journal of Apicultural Research 48(2): 104-1 14. DOI: 10.3896/IBRA. 1.48.2.04

Linskens H. F., Jorde W. (1997) Pollen as food and medicine: a review. Economic Botany 51 (1): 78-86.

Liolios V., Tananaki C., Dimou M., Kanelis D., Thrasyvoulou A. (2010) Protein content and sugar composition of bee-collected pollen from selected botanical origins. In: Abstracts: International Symposium on Authenticity 


\section{J. APPC. SCL. VOL. 58 N NO. 220014}

and Quality of Bee Products and 2nd World Symposium on Honeydew Honey. Chania - Crete. 7 - 10 April 2010. Journal of ApiProduct and ApiMedical Science 2(3):1 16.

Louveaux I., Maurizio, A., Vorwohl G. (1978) Methods of Melissopalynology. Bee World 59(4): 139-157.

McLellan A. R. (1974) Some effects of pollen traps on colonies of honey bees. Journal of Apicultural Research 13(2): 143-148.

Moshidis G., Dimou M., Tananaki C., Thrasyvoulou A. (2013) Pollen atlas of Rhodes island, Greece. In: Proceedings of 43rd International Apimondia Congress. Kyiv - Ukraine. 29 September - 04 October 2013: 359.

Novais J. S., Lima L. C. L., Santos F. A. R. (2010) Bee pollen loads and their use in indicating flowering in the Caatinga region of Brazil. Journal of Arid Environments 74(10): 1355-1358. DOl: 10.1016/j.jaridenv.2010.05.005

Papapanagiotou E. (2010) Economic analysis of beekeeping in Greece. Project report for research program of the Department of Agricultural Economics. Faculty of Agriculture, Aristotle University of Thessaloniki. ThessaIoniki, Greece. 78 pp. Available at: http://www.melinet.gr/ docs/oikonom_anal_melis.pdf

Phitos D., Strid A., Snogerup S., Greuter, W. (1995) The red data book of rare and threatened plants of Greece, Athens, World Wildlife Fund for Nature. 527 pp.

Roulston T. H., Cane J. H. (2000) Pollen nutritional content and digestibility for animals. Plant Systematics and Evolution 222(1-4): 187-209.
Roulston T. H., Cane J. H., Buchmann S. L. (2000) What governs protein content of pollen: pollinator preferences, pollen-pistil interactions or phylogeny? Ecological Monographs 70(1): 617-643. DOl: 10.1890/0012-9615(2000)070[0617:WGPCOP]2.0. $\mathrm{CO} ; 2$

Shannon C. E., Weaver W. (1949) The mathematical theory of communication. University of Illinois Press. Urbana. $117 \mathrm{pp}$

SPSS 17.0 software for Windows. SPSS, Chicago, IL, USA.

Szczęsna T. (2006) Protein content and amino acid composition of bee-collected pollen from selected botanical origins. Journal of Apicultural Science 50(2): 81-90.

Thrasyvoulou A., Manikis J. (1995) Some physicochemical and microscopic characteristics of Greek unifloral honeys. Apidologie 23(6): 441 -452. DOI: 10.1051/apido:1995060

Tsigouri A., Passaloglou-Katrali M., Sabatakou 0. (2004) Palynological characteristics of different unifloral honeys from Greece. Grana 43(2): 122-128. DOl: 10.1080/00173130310017643

Villanueva M. T. O., Marquina A. D., Serrano R. B., Abellán G. B. (2002) The importance of bee-collected pollen in the diet: a study of its composition. International Journal of Food Sciences and Nutrition 53(3): 217-224.

Wróblewska A., Warakomska Z., Kaminska M. (2010) The pollen spectrum of bee bread from the Lublin Region (Poland). Journal of Apicultural Science 54(2): 81-89. 